\title{
Antidiabetic and Antioxidant Profile of Three Varieties of Passion Fruit
}

\author{
Julia Sebastian and Shilpa Jose* \\ Department of Home Science, Faculty of Food Science and Nutrition, St. Teresa's College (Autonomous), Ernakulam \\ -682011, Kerala, India; shilpajose2017@gmail.com
}

\begin{abstract}
The present study was undertaken to assess the anti-diabetic potential and antioxidant profile of three different varieties of passion fruit that are locally available in Kerala. Even though studies have been done on the chemical composition of passion fruit, very few studies have been reported on the nutrient composition and glycemic response of its locally available varieties. The samples selected were purple passion fruit (Passiflora edulis), yellow passion fruit (Passiflora edulis var flavicarpa) and sweet passion fruit (Passiflora ligularis). The nutrients vitamin C, total carotene as well as total fiber content were analysed. Preliminary phytochemical analysis confirmed the presence of tannins, alkaloids and flavonoids in all three samples. Sweet passion fruit had the highest content of total phenol followed by yellow and purple varieties respectively. The free radical scavenging activity of the selected varieties of passion fruit was measured using the stable radical DPPH assay. Alpha amylase inhibition assay was done to assess the anti-diabetic activity. Yellow passion fruit had the highest content of vitamin C $(36.34 \mathrm{mg} / 100 \mathrm{~g})$ and total carotene $(91 \mu \mathrm{g} / 100 \mathrm{~g})$ as well as total antioxidant activity $\left(\mathrm{IC}_{50}\right.$ of 149.623$)$ whereas sweet passion fruit exhibited highest fiber content $(11.5 \mathrm{mg} / 100 \mathrm{~g})$ and total phenol content $(31.4 \mathrm{mg}$ $\mathrm{GAE} / \mathrm{g}$ ). The highest anti-diabetic property was shown by the purple passion fruit (146). Thus the present study revealed that the selected varieties of passion fruit have good antioxidant profile and significant anti-diabetic potential.
\end{abstract}

Keywords: Antioxidant Activity, Anti Diabetic Potential, Passion Fruit

\section{Introduction}

Like vegetables, fruits can be classified as berries, pomaceous fruits or citrus fruits. Unlike vegetables, which are usually eaten at meals, fruits are often used as a dessert or eaten as a snack between meals. They are an important source of phytochemicals, minerals, vitamins, trace elements, fibre and contain very little fat. Fruits consumption has a number of health benefits mainly because of the presence of various biologically active substances in them. Apart from the high nutrient density, most fruits have high water content and are also relatively low in calories ${ }^{1}$.

The passion fruit originated from the tropical regions of America like Brazil where there is a distribution of almost 150 species of this family ${ }^{2}$. It belongs to the family of Passifloraceae, genus Passiflora and comprises of about 530 species. This is a high value and export oriented crop and it is grown extensively in the tropical and subtropical regions. In India, passion fruit is cultivated in places like Kerala, Tamil Nadu (Nilgiri hills and Kodaikanal), Karnataka (Coorg) and northeastern states (Mizoram, Nagaland, Manipur and Sikkim). A number of fruits of the Passifloraceae family have been found to possess

${ }^{*}$ Author for correspondence 
antidiabetic as well as antioxidant properties.

Medicinally, passion fruit has been used for the prevention of yellow fever, gallstones, rabies and ulcers. A leaf decoction $n$ was also prescribed for easing stomach upsets and for preventing malaria and other fevers. A study by Joy et al. , mentioned that "Passion fruit is proved to have analgesic, antianxiety, anti-inflammatory, antispasmodic, cough suppressant, aphrodisiac, central nervous system depressant, diuretic, hypotensive and sedative activities. It is also traditionally believed to have anticonvulsant, antidepressant, astringent, cardiotonic, tranquilizer and vermifuge activities. It also has effects on neurological disorders and chronic diseases such as heart disease and cancer".

\section{Materials and Methods}

\subsection{Collection and Extraction of Plant}

\section{Material}

The passion fruits were purchased from a local market in Kochi. The pulp was separated and used for analysis.

Ethanolic extracts were used for the phytochemical screening and determination of total phenol content. Pulp of the passion fruit was taken and homogenized using ethanol for the preparation of ethanolic extracts. 10 $\mathrm{g}$ of the samples were ground in a motar and pestle and were homogenized using $100 \mathrm{ml}$ ethanol. The extracts were kept in a shaker for 24 hours and filtered and the extract was used for the study.

For the DPPH Assay and Alpha amylase inhibition assay, $1 \mathrm{~g}$ pulp was collected and crushed with $1 \mathrm{ml}$ distilled water; centrifuged at $5000 \mathrm{rpm}$. The supernatant was collected and used for the assays.

\subsection{Analysis of Nutrients}

Vitamin C was estimated by dye method, carotene was analyzed using Arnon ${ }^{4}$ method and conventional method proposed by Raghuramulu et al. ${ }^{5}$ was followed for the estimation of fiber content.

\subsection{Preliminary Phytochemical Screening}

The alkaloid content of the samples was detected using Mayer's test and Wagner's test $t^{\underline{6}}$. The test for tannins was done using lead acetate and ferric chloride test ${ }^{6}$. Alkaline reagent test was used to determine the flavonoid content ${ }^{\underline{6}}$. Saponins were tested using froth test ${ }^{6}$.

\subsection{Quantitative Estimation of Total Phenol Content}

Folin-ciocalteu method ${ }^{7}$ was used to determine the total phenol content.

\subsection{DPPH Radical Scavenging Assay}

DPPH radical scavenging assay was used to determine the total antioxidant activity ${ }^{\underline{6}}$.

$$
\text { Radical scavenging activity }=\frac{\text { Control }- \text { Test }}{\text { Control }} \times 100
$$

\subsection{Alpha Amylase Inhibition Assay}

Alpha amylase inhibition assay was used to determine the anti diabetic activity ${ }^{8}$. The half maximal inhibitory concentration $\left(\mathrm{IC}_{50}\right)$ is a measure of the potency of a substance in inhibiting a specific biological or biochemical function by half.

Percentage Inhibition $=\frac{\text { Optical Density ofControl }- \text { Optical Density of Test }}{\text { Optical Density of Control }} \times 100$

\section{Results and Discussion}

\subsection{Nutrient Content of Passion Fruit}

Vitamin C content of selected varieties of passion fruit was analyzed (Table 1). It was observed that yellow passion fruit had the highest content of Vitamin C (36.34mg) followed by sweet passion fruit $(20.76 \mathrm{mg})$

Table 1. Nutrient content in selected varieties of Passion Fruit

\begin{tabular}{|c|c|c|c|c|}
\hline Sl.No & Sample & $\begin{array}{c}\text { Vitamin C } \\
(\mathrm{mg} / 100 \mathrm{~g})\end{array}$ & $\begin{array}{c}\text { Total Carotene } \\
(\mu \mathrm{g} / \mathbf{1 0 0 g})\end{array}$ & $\begin{array}{c}\text { Fiber } \\
(\mathrm{mg} / \mathbf{1 0 0 g})\end{array}$ \\
\hline 1. & Purple Passion Fruit & 15.57 & 74.33 & 8.23 \\
\hline 2. & Yellow Passion Fruit & 36.34 & 91 & 8.33 \\
\hline 3. & Sweet Passion Fruit & 20.76 & 28.97 & 11.5 \\
\hline
\end{tabular}


and purple passion fruit $(15.7 \mathrm{mg})$ respectively. Total carotene content among the selected varieties of passion fruit varied. Yellow passion fruit $(91 \mu \mathrm{g})$ had the highest content of total carotene, followed by purple passion fruit $(74.33 \mu \mathrm{g})$ and sweet passion fruit $(28.97 \mu \mathrm{g})$ respectively. However it was observed that sweet passion fruit $(11.5 \mathrm{mg})$ has a higher content of fiber, followed by yellow passion $(8.33 \mathrm{mg})$ fruit and purple passion fruit $(8.23 \mathrm{mg})$ respectively.

\subsection{Phytochemical Screening}

Preliminary phytochemical analysis of the extracts of all the three samples showed the presence of major classes of phytochemicals such as Total phenols, alkaloids and flavonoids.

\subsection{Quantitative Estimation of Total Phenol Content}

"Phenolic compounds areplant secondary metabolites, and they play a major role as defence compounds. Several properties beneficial to humans are exhibited by phenolics and its antioxidant properties are significant in defining their role as agents protecting against free radicalmediated disease processes". Phenolic compounds have redox properties, which allow them to act as antioxidants. So the total phenolic concentration could be used as a basis for rapid screening of antioxidant activity.

Total phenol content at $2,4,6,8 \mathrm{ml} / \mathrm{mg}$ concentrations of gallic acid in purple passion fruit ranged from $3 \mathrm{mg}$ GAE/g to $10.2 \mathrm{mg} \mathrm{GAE} / \mathrm{g}$, from $2.4 \mathrm{mg} \mathrm{GAE} / \mathrm{g}$ to $12.1 \mathrm{mg}$

Table 2. Total phenol content of Passion Fruit

\begin{tabular}{|c|c|c|c|}
\hline $\begin{array}{c}\text { Concentration of gallic } \\
\text { acid (mg/ml) }\end{array}$ & $\begin{array}{c}\text { Purple passion } \\
\text { fruit (mg GAE/g) }\end{array}$ & $\begin{array}{c}\text { Yellow passion } \\
\text { fruit (mg GAE/g) }\end{array}$ & $\begin{array}{c}\text { Sweet passion fruit } \\
\text { (mg GAE/g) }\end{array}$ \\
\hline 0 & 0 & 0 & 0 \\
\hline 2 & 3 & 2.4 & 5.2 \\
\hline 4 & 6.2 & 5 & 29.8 \\
\hline 6 & 8.8 & 11 & 31.4 \\
\hline 8 & 10.2 & 12.1 & 29 \\
\hline
\end{tabular}

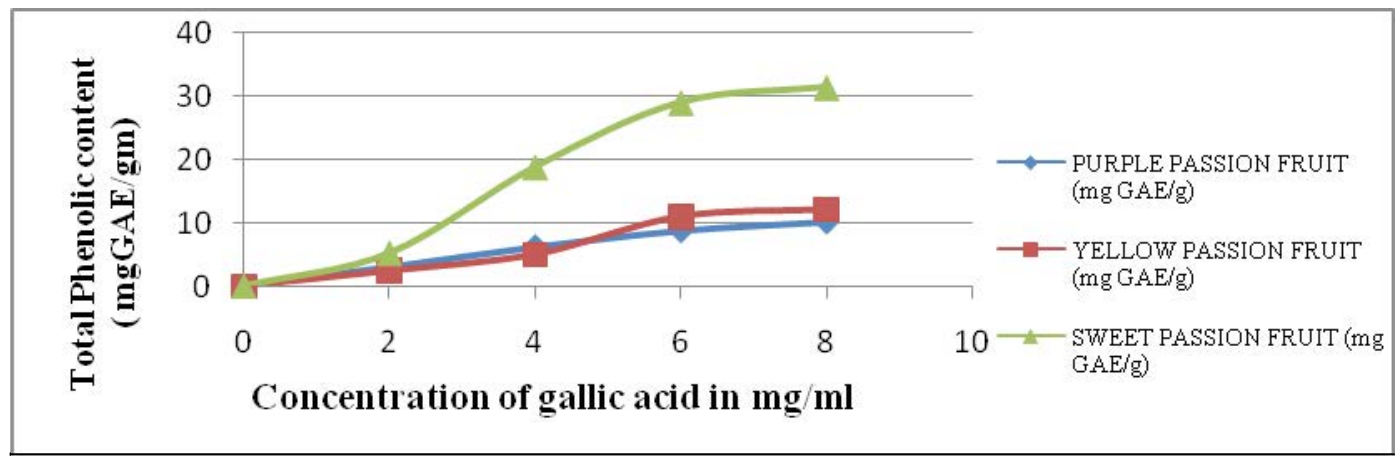

Figure 1. Total phenol content of selected varieties of Passion Fruit. 
Table 3. Total Antioxidant Activity of selected varieties of Passion Fruit using DPPH Assay.

\begin{tabular}{|c|c|c|c|}
\hline Sample & Concentration (mg) & $\begin{array}{c}\% \text { of scavenging } \\
\text { activity }\end{array}$ & $\mathrm{IC}_{50}$ value $(\mu \mathrm{g} / \mathrm{ml})$ \\
\hline \multirow{3}{*}{ Yellow passion fruit } & 100 & 24.80 & \multirow{3}{*}{149.623} \\
\hline & 150 & 43.09 & \\
\hline & 200 & 60.37 & \\
\hline \multirow{3}{*}{ Purple passion fruit } & 100 & 30.49 & \multirow{3}{*}{151.046} \\
\hline & 150 & 57.72 & \\
\hline & 200 & 83.54 & \\
\hline \multirow{3}{*}{$\begin{array}{l}\text { Sweet passion } \\
\text { fruit }\end{array}$} & 100 & 36.79 & \multirow{3}{*}{157.468} \\
\hline & 150 & 45.53 & \\
\hline & 200 & 59.15 & \\
\hline
\end{tabular}

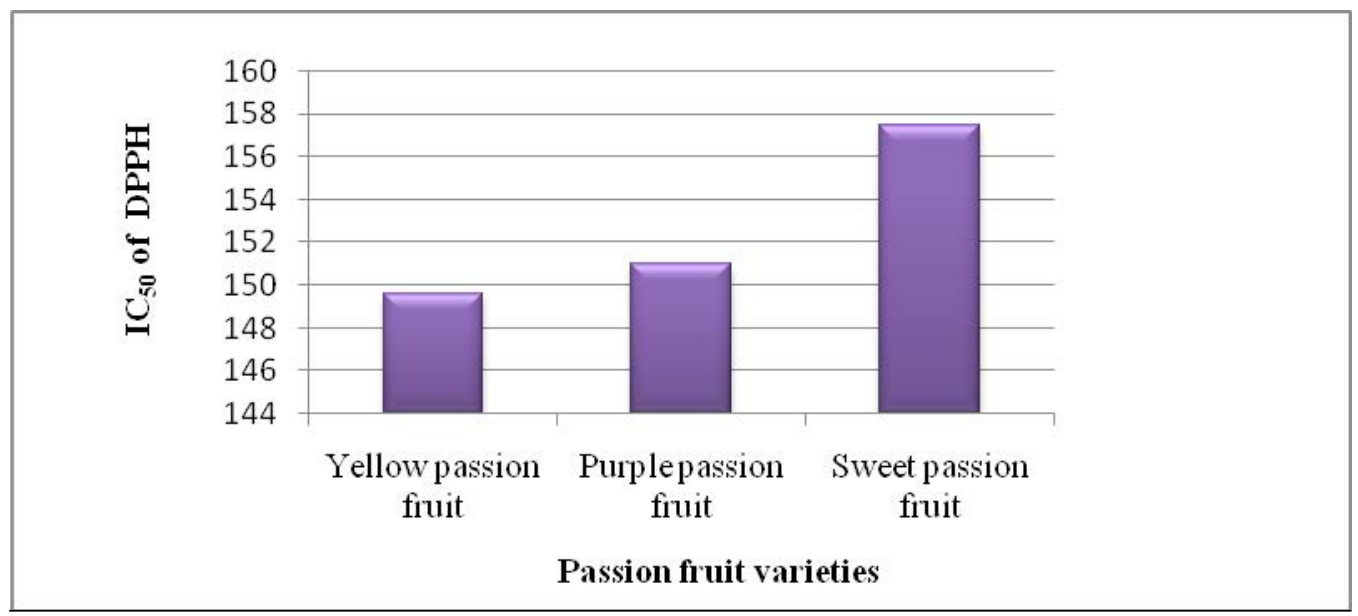

Figure 2. DPPH radical scavenging activity ( $\mathrm{IC}_{50}$ value).

GAE/g in yellow passion fruit and from $5.2 \mathrm{mg} \mathrm{GAE} / \mathrm{g}$ to $31.4 \mathrm{mg} \mathrm{GAE} / \mathrm{g}$ (Table 2) in sweet passion fruit. Thus it was found that sweet passion fruit had the highest total phenol content followed by yellow passion fruit and purple passion fruit respectively (Figure 1).

\subsection{Antioxidant Activity using DPPH Radical Scavenging}

The DPPH radical contains an odd electron, which is responsible for the absorbance at $518 \mathrm{~nm}$. The DPPH is decolorized when it accepts an electron donated by an antioxidant compound, which can be quantitatively measured from the changes in absorbance. Higher DPPH free radical scavenging activity is shown in plants with higher donating capacity.

From Table 3, it can be inferred that the yellow passion fruit showed the highest total antioxidant activity $\left(\mathrm{IC}_{50}\right.$ of 149.623) followed by purple passion fruit $\left(\mathrm{IC}_{50}\right.$ of 151.046) and sweet passion fruit ( $\mathrm{IC}_{50}$ of 157.468). 
Table 4. Anti Diabetic Property of selected varieties of Passion Fruit using

Alpha Amylase Inhibition Assay

\begin{tabular}{|c|c|c|c|}
\hline Sample & Concentration $(\mu \mathrm{L})$ & $\%$ of inhibition & $\begin{array}{c}\mathrm{IC}_{50} \text { value }(\mu \mathrm{g} / \\
\mathrm{ml})\end{array}$ \\
\hline \multirow{3}{*}{ Purple passion fruit } & 100 & 27.24 & \multirow{3}{*}{146.044} \\
\hline & 150 & 54.84 & \\
\hline & 200 & 71.37 & \\
\hline \multirow{3}{*}{ Yellow passion fruit } & 100 & 36.98 & \multirow{3}{*}{152.812} \\
\hline & 150 & 53.88 & \\
\hline & 200 & 76.94 & \\
\hline \multirow{3}{*}{ Sweet passion fruit } & 100 & 34.00 & \multirow{3}{*}{154.404} \\
\hline & 150 & 49.50 & \\
\hline & 200 & 74.35 & \\
\hline
\end{tabular}

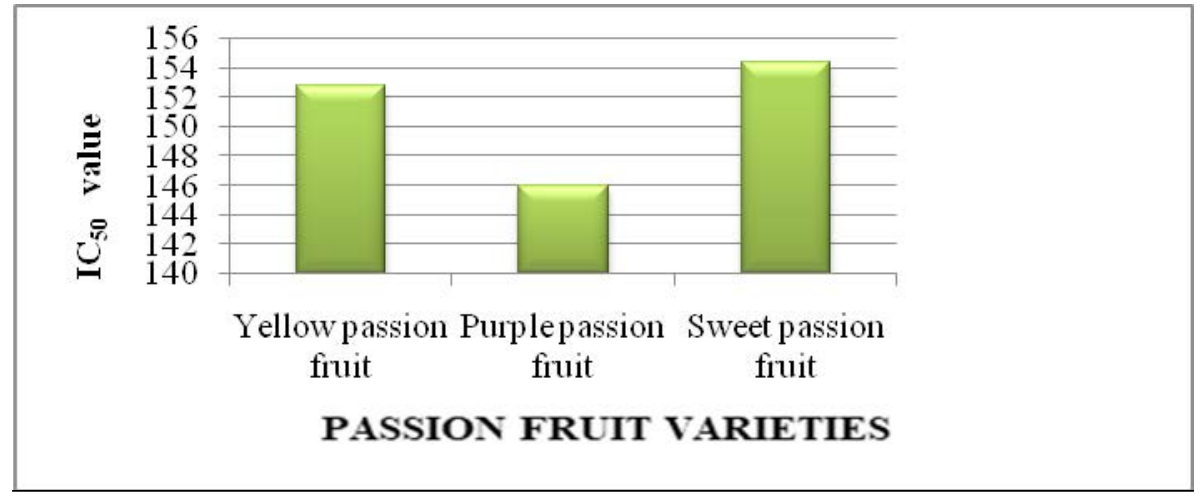

Figure 2. Alpha amylase inhibition activity $\left(\mathrm{IC}_{50}\right.$ value).

\subsection{Alpha Amylase Inhibition Activity}

The treatment of diabetes involves the reduction in postprandial hyperglycemia by retarding the distillation of glucose through inhibition of carbohydrate hydrolyzing enzymes like $\alpha$-amylase and $\alpha$-glucosidase. A good scheme to manage postprandial hyperglycemia with lesser side effects is to assess the natural inhibitors from food which has less inhibitory effect against $\alpha$-amylase.

It was observed that all three varieties had significant Alpha amylase inhibition activity (Figure 2) with highest activity being shown by purple passion fruit with an $\mathrm{IC}_{50}$ value of 146.04 (Table 3) followed by the yellow passion fruit and the sweet passion fruit with $\mathrm{IC}_{50}$ values 152.81 and 154.40 respectively. This can act as the natural source with less inhibitory effects against $\alpha$-amylase to manage post prandial hyperglycemia.

\section{Conclusion}

Yellow passion fruit had the highest content of vitamin $\mathrm{C}(36.34 \mathrm{mg} / 100 \mathrm{~g})$ and total carotene $(91 \mu \mathrm{g} / 100 \mathrm{~g})$ as well as total antioxidant activity $\left(\mathrm{IC}_{50}\right.$ of 149.623 ) whereas sweet passion fruit exhibited highest fiber content 
$(11.5 \mathrm{mg} / 100 \mathrm{~g})$ and total phenol content (31.4mg GAE/g). The highest anti-diabetic property was shown by the purple passion fruit $(146 \mu \mathrm{g} / \mathrm{mL})$.

The presence of phenols and flavonoids contributed significantly to the hypoglycemic activity of passion fruit. The presence of numerous antioxidant phytochemicals present in passion fruit enhance its therapeutic significance. Therefore, it can be concluded that the three different varieties of passion fruit possess significant anti-diabetic activity and it may prove to be effective for the management of diabetes. The selected varieties also exhibited antioxidant activity which contributes to the therapeutic effects on oxidant stress.

\section{References}

1. Boeing H, Bechthold A and Bub A. Critical review: vegetables and fruit in the prevention of chronic diseases. European Journal of Nutrition. 2012; 51(6):637-63. https:// doi.org/10.1007/s00394-012-0380-y PMid:22684631 PMCid:PMC3419346

2. Bernacci LC, Meletti LMM, Soares-Scott MD, Passos IRS and Junqueira NNT. Passionflower species: characterization and conservation of biodiversity. Passionflower: germplasm and breeding. Embrapa Cerrados, Planaltina. 2005; p. $559-86$.

3. Joy PP, Thomas J, Mathew S and Skaria BP. Medicinal plants, in Tropical Horticulture. Bos TK, Kabir J, Das P, Joy PP, Eds., Medicinal Plants. Naya Prokash, Calcutta, India. 2010; 2:449-632.

4. Raghuramulu N, Madhavan Nair K and Kalyanasundaram S. A Manual of Laboratory Techniqaues, 2nd edition. National Institute of Nutrition, Hyderabad. 2003; p. 57, 157, 158.

5. Arnon DI. Copper enzymes in isolated chloroplasts, polyphenol oxidase in Beta vulgaris. Plant Physiology. 1949; 2:1-15. https://doi.org/10.1104/pp.24.1.1

6. Ayoola GA, Coker HAB, Adesegun SA, Adepoju-Bello AA, Obaweya K, Ezennia EC and Atangbayila TO. Phytochemical Screening and Antioxidant Activities of Some Selected Medicinal Plants Used for Malaria Therapy in Southwestern Nigeria. Tropical Journal of Pharmaceutical Research. 2008; 7(3):1019-24.

7. Ferreira ICFR, Baptista P, Vilas-Boas M and Barros L. Free radical scavenging capacity and reducing power of wild edible mushrooms from northeast Portugal: Individual cap and stipe activity. Food Chemistry. 2007; 100:1511-6. https://doi.org/10.1016/j.foodchem.2005.11.043

8. Xiao Z, Storms R and Tsang A. A quantitative starch-iodine method for measuring alpha-amylase and glucoamylase activities. Analytical Biochemistry. 2006; 351(1):146-8. https://doi.org/10.1016/j.ab.2006.01.036 PMid:16500607

9. Dai J and Mumper R. Plant phenolics: extraction, analysis and their antioxidant and anticancer properties. Molecules. 2010; 15:7313-52. https://doi.org/10.3390/molecules15107313 PMid:20966876 PMCid:PMC6259146 